\title{
Factors Influencing Bachelor of Education Arts Students' Selection of History as Career Subject: Case of University of Nairobi, Kenya
}

\author{
Joseph Ogutu Owino ${ }^{*}$, Paul Amolloh Odundo \\ Department of Educational Communication and Technology, University of Nairobi, Kenya
}

Copyright $(2016$ by authors, all rights reserved. Authors agree that this article remains permanently open access under the terms of the Creative Commons Attribution License 4.0 International License

\begin{abstract}
History is one of the teaching subjects studied by Bachelor of Education Arts students at the University of Nairobi. In the last five years, there has been a tremendous increase in the number of students specializing in History as a teaching subject. This paper therefore has examined factors influencing students' selection of History as career subject. The specific objectives were to examine the factors that influenced students' specialisation in History as a career subject and to assess students' attitude towards pursuing a career in History after university education. The study was based on across-sectional survey design. A structured questionnaire was used to collect data from 110 students at the University of Nairobi. Data were analysed quantitatively using SPSS and presented in form of tables. Findings of the study revealed that personal interests, parental guidance, career guidance and influence of lecturers all had an impact on students' specialisation in History. The findings of the study further pointed out that some students had trouble in selecting specialisation subjects due to lack of proper guidance. The study, therefore, recommends proper guidance of students on subject specialisation.
\end{abstract}

Keywords Factors, Influence, Bachelor, Education, Students, Selection, History, Career Subject

\section{Introduction}

Vocational choice is an important decision that shapes a student's life. According to Alberts et al. [1], a person's vocation choice has a great influence on his or her social and economic conditions. They argue that personal interests, parental guidance, peer pressure and institutional regulations influence students' career choices. Students who are misguided during selection of career subjects often experience challenges during and after their studies [1]. A student who chooses a complicated career subject can be compelled to drop it due to poor performance. In addition, students who make wrong career decisions due to misguidance often join vocations they are not interested in pursuing. Lack of interest in a given career can lead to poor performance at work due to lack of self-satisfaction. Furthermore, individuals who are less motivated at work cannot make any meaningful contribution to the development of the society. This study therefore examined the factors influencing selection of History as career subject among Bachelor of Education Arts students at the University of Nairobi.

According to Wilhelm [2], subject instructors have significant influence on how students perceive the usefulness of a particular subject. Another study by Curran and Rosen also indicated that instructors influence students' subject preference. They however noted that most students tend to have a larger preference for the knowledge they receive from subject as opposed to an instructor's influence. Babad and Taybe [3] argue that instructional styles are as important as the quality of the subject matter being taught. Consequently, students' attitudes towards an instructor largely influence their attitude towards a given subject. They further note that students tend to prefer subjects whose instructors are knowledgeable, enthusiastic and articulate as opposed to those who are inflexible and less enthusiastic [3]. Conversely, inflexible and unclear instructors are usually unpopular among students because they find it difficult to learn from them.

Personality traits influence career choices in different ways. According to Hooley [4], outgoing individuals may opt for careers in politics or in sales and marketing where they are more likely to perform better as opposed to quiet and introverted individuals. Hooley [4] notes that an individual's occupational choice is an expression of his or her personality. People of a given occupational group are more likely to have similar personalities. The congruence between personality and work environment influences occupational achievement, stability and satisfaction. However, it is worth noting that majority of occupations can be undertaken by people with different personality characteristics. According to Park [5], 
personal interests significantly influence occupational choices. As a person engages in different activities, he or she usually reacts to specific feelings and attitudes that results from the activities. The personal reactions and feedbacks that one receives usually shape and focus one's interests on a given career. Park [5] therefore concludes that interest inventories help individuals in the identification of interests, which they relate to careers and occupations. Students' perceptions about certain domains usually affect their choice of specialisation subjects [6]. For instance, a student who has developed a negative attitude towards a given subject can avoid pursuing it. On the contrary, a positive attitude leads to a positive commitment to a given subject [6]. A student also can choose a career subject based on how he or she perceives an ideal career [7]. Therefore, one's perception about the perfect job inspires subject specialisation.

According to Okeke [8], parents significantly influence their children's career choices compared to guidance and counselling teachers. A study by Malgwi, Howe and Burnaby [9] also indicated that family members are more influential in student's choice of subjects and courses compared to teachers who are supposed to guide students in subject selection. Mothers tend to have more influence on their children's choices during high school years, while fathers are more influential in their children's career decision-making during college years. Parental influence can translate to increased student enrolment in more classes, especially if parents believe that their children are able to excel in the classes chosen [10]. Parental occupational status has also an influence on their children career choices whereby children who are brought up in a harmonious family environment are more likely to emulate their parents' careers [11]. Societal values play a crucial role in influencing students' career choices [12]. Students usually uphold values they have acquired from society. Therefore, careers that may undermine such values are unlikely to be pursued.

\subsection{Statement of the Problem}

The University of Nairobi offers Bachelor of Education Arts (BEDA), which is a four-year undergraduate degree programme pursued by students aspiring to join the teaching profession. This programme offers flexible subject specialization options for students based on the following criteria. For a student to pursue BEDA, they must have attained at least a mean grade of $\mathrm{C}+$ in the Kenya Certificate of Secondary Education (KSCE). Second, they must have scored at least $\mathrm{C}+$ in any two teaching subjects, which include English, Literature, Kiswahili, Mathematics, Religious Studies, Geography, History, Business studies and Physical Education. Selection of teaching subjects also is based on guidelines recommended by the Teachers Service Commission (TSC). Although BEDA students specialize in various teaching subjects, they often face challenges in making right subject choices because many factors influence their career decisions. For example, many students specialized in Mathematics and Business studies instead of History in the 1990s. However, the $21^{\text {st }}$ century has witnessed a tremendous increase in the number of students specializing in History compared to other disciplines that earlier attracted many students. Based on the work of Ahmed and Sajjad [12] students usually get inconsistent assistance from various sources, including parents, teachers, and vocational trainers. As such, once they join institutions of higher learning, they are most likely to experience discrepancy between actual experiences and expectations. This study, therefore, sought to find out factors influencing Bachelor of Education Arts students' selection of History as career subject, with reference to University of Nairobi. The recommendations of this study can enable the university administration to offer better career guidance and counselling to students.

\subsection{Objectives}

The study was guided by the following specific objectives i. Examine the factors that influence students' specialisation in History as a career subject.

ii. Assess students' attitude towards pursuing a career in History after university education.

\subsection{Conceptual Framework}

The theory of attitude formation advanced by Radford and Govier [13] and Feldman [14] guided the formulation of the conceptual framework on the factors influencing students' choice of History. The conceptual framework shows that individual factors, college career guidelines and environmental factors are determinants of students' specialization in History. These factors are interrelated and they all influence students' decision to specialize in History. Radford and Govier [13] contend that multiple elements found in a given system have profound influences on choice. Feldman [14] observed that an alteration in a single element leads to system and that these elements are interdependent. 


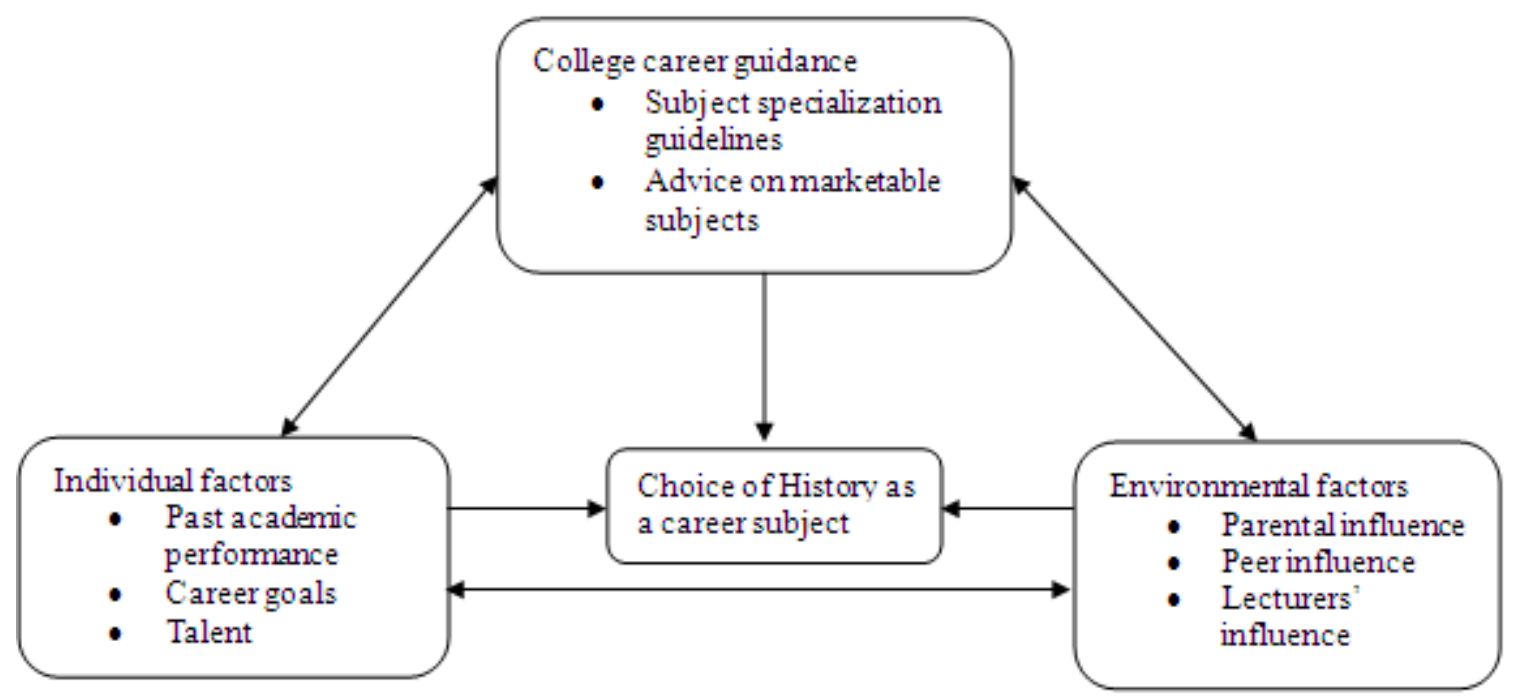

Figure 1.Factors influencing students' choice of History

Based on this observation, any changes in an individual's choice is a function of changes in other elements. Evidence has shown that both cognitive and affective elements of attitude have some close relations. The affective element reflects positive or negative emotions about individuals' feelings [14]. Conversely, the behavior aspect shows intention or the tendency to act in a given way based on a person's preference. Finally, the cognitive element focuses on beliefs and thoughts of an individual reflected on preference. As such, students may opt for History as a field that is important and, thus, this notion leads to formation of preference. For example, a learner's preference to History may be a function of positive emotions identified as affective elements. The intention to teach the subject is noted as the behavior aspect while the belief that teaching of the subject as a career is beneficial is regarded as the cognitive component. Individuals' preferences however are hypothetically formed and cannot be directly observed. As such, the existence of such preferences is only deduced from one's behaviors based on reasons provided for choosing the subject. The behavior could be attributed to influences that emanate from different sources, including environmental influence and cognitive related factors [14].

\section{Methodology}

In this study, data were collected from students at a specific period at the University of Nairobi using across-sectional survey design. The study population consisted of third and fourth year students of Bachelor of Education Arts enrolled for the academic year 2014/2015. 110 students were randomly selected from class lists. A structured questionnaire with three sections was used in collecting data from the respondents. Section A of the questionnaire gathered background information about participants. Section B examined factors that influenced career choice and the impact of career guidance on the same. Section C focused on participants' attitudes toward pursuing a career in History after graduation. The respondents' attitudes were measured using a three-point Likert scale consisting of Agree, Don't Know, and Disagree. Open-ended questions were used to capture qualitative information on the participants' opinions on choice of History as career subject. A pilot study was conducted to test the study instrument for reliability using six participants randomly selected from Nairobi University. Their responses were used to review research questions, change ambiguous ones, and improve on seemingly difficult questions [15]. All the 110 questionnaires were administered and completed successfully; hence, the response rate was $100 \%$. Data collected were confidential. The Statistical Packages for Social Scientists (SPSS) version 16 was applied in analysis of quantitative data. Moreover, analysis of quantitative data involved data cleaning, coding, and categorising based on specific themes identified from responses. The analysed data were presented in tables with frequencies and percentages. Qualitative data were presented as narratives through direct quotes from respondents. Secondary data derived from books and journal articles corroborated primary information.

\section{Findings}

\section{Demographic characteristics}

The demographic characteristics of participants were used as the basis for the interpretation of the study findings. Hence, data collected from respondents captured various age groups, gender, and types of university sponsorship. Table 1 and 2 summarized the demographic results.

Table 1 shows that majority of the respondents $101(91.9 \%)$ were in the age bracket of (16 -20 years) and 7(6.6\%) of the respondents were in the age bracket of (21-25 years). Only $2(1.8 \%)$ of the respondents were in the age bracket of (26-30 years). This finding indicates that majority of the students were young and less experienced in career matters; hence, they required proper guidance to make informed subject choices. Cumulatively, more male 66(60\%) than female $44(40 \%)$ respondents pursued Bachelor of Education Arts. 
Table 1. Distribution of participants by gender and age

\begin{tabular}{|c|c|c|c|c|c|c|c|}
\hline \multirow{3}{*}{ Gender } & \multicolumn{6}{|c|}{ Age brackets of the respondents } & \multirow{3}{*}{ Total } \\
\hline & \multicolumn{2}{|c|}{$(16-20)$ years } & \multicolumn{2}{|c|}{$(21-25)$ years } & \multicolumn{2}{|c|}{$(26-30)$ years } & \\
\hline & Frequency & Percentage & Frequency & Percentage & Frequency & Percentage & \\
\hline Male & 61 & $55.5 \%$ & 3 & $2.7 \%$ & 2 & $1.8 \%$ & $66(60 \%)$ \\
\hline Female & 40 & $36.4 \%$ & 4 & $3.6 \%$ & 0 & $0 \%$ & $44(40 \%)$ \\
\hline Total & 101 & $91.9 \%$ & 7 & $6.6 \%$ & 2 & $1.8 \%$ & $110(100 \%)$ \\
\hline
\end{tabular}

Table 2. Type of sponsorship of Bachelor of Education Arts students

\begin{tabular}{|c|c|c|c|c|c|}
\hline \multirow{2}{*}{ Gender } & \multicolumn{4}{|c|}{} & \multirow{2}{*}{ Total } \\
\cline { 2 - 6 } & \multicolumn{2}{|c|}{ Government } & \multicolumn{2}{|c|}{ Private } & \\
\cline { 2 - 6 } & Frequency & Percentage & Frequency & Percentage & \\
\hline Male & 55 & $50 \%$ & 19 & $17.3 \%$ & $74(67.3 \%)$ \\
\hline Female & 25 & $22.7 \%$ & 11 & $10 \%$ & $36(32.7 \%)$ \\
\hline Total & 80 & $72.7 \%$ & 30 & $27.3 \%$ & $110(100 \%)$ \\
\hline
\end{tabular}

The results in table 2 show that $80(72.7 \%)$ of the respondents were government-sponsored and $30(27.3 \%)$ were self-sponsored. However, there were more government-sponsored male students 55(50\%) than female students $25(22.7 \%)$. This finding suggests that academic qualification and not gender consideration was the key determinant of government sponsorship of university students. Although the government sponsored majority of the Bachelor of Education Arts students, some of them enrolled for the course as a second option because they did not qualify to pursue other government-sponsored courses. On the other hand, majority of self-sponsored students pursued Bachelor of Education Arts out of their own interests. The low enrolment of self-sponsored students in Bachelor of Education Arts degree indicates that higher education in Kenya is expensive and out of reach of many students.

Table 3. Determinants of choice of History as a teaching subject

\begin{tabular}{|c|c|c|c|c|c|}
\hline \multirow{2}{*}{ Reasons for choosing to study History } & \multicolumn{2}{|c|}{ Male } & \multicolumn{2}{|c|}{ Female } & \multirow{2}{*}{ Total } \\
\hline & Frequency & $\%$ & Frequency & $\%$ & \\
\hline Personal interest & 21 & $19.1 \%$ & 14 & $12.7 \%$ & $35(31.8 \%)$ \\
\hline Parental/family influence & 8 & $7.3 \%$ & 16 & $14.5 \%$ & $24(21.8 \%)$ \\
\hline Availability of job opportunities & 14 & $12.7 \%$ & 12 & $10.9 \%$ & $26(23.6 \%)$ \\
\hline Previous academic performance in History & 6 & $5.5 \%$ & 9 & $8.1 \%$ & $15(13.6 \%)$ \\
\hline Lecturer's influence & 4 & $3.6 \%$ & 6 & $5.6 \%$ & $10(9.1 \%)$ \\
\hline Total & 53 & 48.2 & 57 & 51.8 & $110(100 \%)$ \\
\hline
\end{tabular}

The findings in table 3 indicate that 21(19.1\%) male and $14(12.7 \%)$ female respondents chose History as a teaching subject because of their personal interest. Whereas $8(7.3 \%)$ male and 16(14.5\%)female respondents chose History because of parental influence. Availability of job opportunities had an influence on 14(12.7\%) male and $12(10.9 \%)$ female respondents' choice of History. This finding explains the dramatic increase in the specialisation in History in the last five academic years. Many students tend to specialize in teaching subjects that are highly demanded in the teaching job market. Previous academic performance had an influence on 6(5.5\%) male and 9(8.1\%) female respondents' choice of History. Lecturer' influenced 4(3.6\%) male and $5.6 \%$ female respondents' choice of History. When asked to explain the reasons for choosing History, one of the respondents commented:

I chose to study History because I like it and I have always wanted to be a teacher. My mother who is a retired teacher also encouraged me to join the teaching profession. I also chose to study History because I excelled in it during my secondary school education. As a teacher trainee, my History lecturer has always encouraged me to specialize in it because currently it has many job opportunities compared to other teaching subjects.

According to Park [5], an individual's motivation to a study a given subject is influenced by life objectives that 
initiate attitudes towards a given field. In this case, people tend to realise more value and personal fulfilment associated with work identity. Spraggs [16] observed that wealthy families have often a provision to allow the eldest son to inherit the family wealth; the second son may become a clergy while the third son may join the military. For younger sons, life could be more difficult. With possibilities of poor job prospect, others would turn to crime, and if they were caught and displayed remorse, then they were most likely to be pardoned. Some recent literature has shown that variations in marriage patterns and career options based on birth orders have emerged. According to Shumba and Naong [17], the eldest son, for example, instead of the younger son was most likely to follow his father's occupation. This observation was not the same in the case of girl child.

Park [5] noted that learners' subject choices are majorly influenced by peer pressure, parental will and academic competence. Nevertheless, peer pressure and parental guidance play significant roles relative to academic prowess (Kniveton, 2004). Peer pressure was associated with positive outcomes on subject selection among students and subsequent performances. Previously, Babad and Tayeb (2003) had reported that learners liked peer support on their choice of subjects and vocational endeavours. Further research has demonstrated that peer support was positively correlated with learners' academic performance and school subject choices [18]

The study sought to establish if career guidelines influenced students' specialisation in History. The findings in table 4 indicate that career guidelines influenced $20(18.2 \%)$ maleand $31(28.2 \%)$ female respondents' specialisation in History. 18(16.4\%) of male and 14(12.7\%) of female respondents reported that career guidelines had limited influence on their specialisation in History. Whereas $15(13.6 \%)$ of male and $8.2 \%$ of the female respondents reported that career guidance did not influence their choice of History, only $1(0.9 \%)$ male and $2(1.8 \%)$ female respondents indicated that there was no career guidance during their choice of History. When asked to comment on the influence of career guidance on choice of History, one of the respondents stated:

................ I sought career guidance from the dean of students and one of the lecturers before choosing specialisation subjects. They both encouraged me to specialize in History since it has many job opportunities. If it were not for their professional guidance, I could have not made correct subject choices. Career guidance therefore had a great influence on my choice of History.

A study by Malgwi et.al [5] pointed out the relevance of career counselling and its impacts on nurturing self-efficacy beliefs and increasing career fields. This practice is imperative for career counsellors who understand the relevance of self-efficacy and its effects on career assessment for effectual career development in learners. Tenenbaum [8] noted that students should seek career counselling from qualified counsellors to assist them realise their actual potential. Career counselling helps in assessing one's personality, aptitude and interests.

According to Ahmed and Sajjad [12], families and schools have fundamental roles to play in providing information and guidance to learners, either directly or indirectly, when they make career choices. Teachers have capabilities to note their students' abilities and aptitudes and encourage their students to pursue specific subjects, engage in work experience or conduct employment visits. The study further pointed out that parents greatly influence their children's career subject choices through offering examples [12]. Additionally, they also provide effective support for specific career choices, which usually tend to reflect their own. The family also offers more influences on career choices.

Table 4.Influence of career guidelines on students' selection of History

\begin{tabular}{|c|c|c|c|c|c|}
\hline \multirow{2}{*}{ Influence of career guidance } & \multicolumn{2}{|c|}{ Male } & \multicolumn{2}{c|}{ Female } & \multirow{2}{*}{ Total } \\
\cline { 2 - 5 } & Frequency & $\%$ & Frequency & $\%$ & $51(46.4 \%)$ \\
Career guidance had a big influence & 20 & $18.2 \%$ & 31 & $28.2 \%$ & $32(29.1 \%)$ \\
Career guidance had little big influence & 18 & $16.4 \%$ & 14 & $12.7 \%$ & $24(21.8 \%)$ \\
Career guidance had no influence & 15 & $13.6 \%$ & 9 & $8.2 \%$ & $3(2.7 \%)$ \\
There was no career guidence & 1 & $0.9 \%$ & 2 & $1.8 \%$ & $110(100 \%)$ \\
\hline Total & 54 & 49.1 & 56 & $50.9 \%$ & 3 \\
\hline
\end{tabular}


Table 5. Respondent's attitude toward pursuing a career in History

\begin{tabular}{|c|c|c|c|c|c|c|c|}
\hline \multirow{2}{*}{ Attitude statement } & \multicolumn{2}{|c|}{ Agree } & \multicolumn{2}{|c|}{ Disagree } & \multicolumn{2}{|c|}{ Don't know } & \multirow{2}{*}{ Total } \\
\hline & Freq & $\%$ & $\mathrm{Fr}$ & $\%$ & Freq & $\%$ & \\
\hline $\begin{array}{l}\text { I will consider teaching History after } \\
\text { graduation. }\end{array}$ & 90 & $81.8 \%$ & 17 & 15.5 & 3 & $2.7 \%$ & $110(100 \%)$ \\
\hline $\begin{array}{l}\text { I will consider self employment in } \\
\text { History after graduation }\end{array}$ & 100 & $90.9 \%$ & 8 & $7.3 \%$ & 2 & $1.8 \%$ & $110(100 \%)$ \\
\hline I think History is an impressive subject. & 87 & $79.1 \%$ & 13 & $11.8 \%$ & 10 & $9.1 \%$ & $110(100 \%)$ \\
\hline $\begin{array}{l}\text { gill consider pursuing otner careers atter } \\
\text { graduation. }\end{array}$ & 29 & $26.4 \%$ & 60 & $54.5 \%$ & 21 & $19.1 \%$ & $110(100 \%)$ \\
\hline
\end{tabular}

Table 6. Ranking of History as a subject choice

\begin{tabular}{|c|c|c|c|c|c|}
\hline \multirow{2}{*}{ Ranking of History } & \multicolumn{2}{|c|}{ Male } & \multicolumn{2}{c|}{ Female } & \multirow{2}{*}{ Total } \\
\cline { 2 - 5 } & Frequency & $\%$ & Frequency & $\%$ & \\
\hline First choice & 24 & $21.8 \%$ & 31 & $28.2 \%$ & $55(50 \%)$ \\
Second choice & 28 & $25.5 \%$ & 11 & $10 \%$ & $39(35.5 \%)$ \\
Third choice & 9 & $8.2 \%$ & 5 & $4.5 \%$ & $14(12.7 \%)$ \\
Did not apply for the course & 2 & $1.8 \%$ & 0 & $0 \%$ & $2(1.8 \%)$ \\
\hline Total & 53 & $52.8 \%$ & 57 & $47.2 \%$ & $110(100 \%)$ \\
\hline
\end{tabular}

Table 5 shows the respondents attitude toward pursuing a career in History. Out of the $110(100 \%)$ respondents, $90(81.8 \%)$ agreed that they will consider teaching History after graduation, but $17(15.5 \%)$ disagreed. Only $3(2.7 \%)$ of the respondents did not know whether they will teach History. Majority of the respondents 100(90.9\%) affirmed that they will consider self-employment in History after graduating, $8(7.3 \%)$ disagreed and $2(1.8 \%)$ did not know anything about the same. Most of the respondents $87(79.1 \%)$ agreed that History was an impressive subject, 13(11.8\%) disagreed, and 10(9.1\%) did not know. The findings further indicate that $29(26.4 \%)$ of the respondents will consider pursuing other careers after graduation, $60(54.5 \%)$ disagreed, and 21(19.1\%) did not know. This finding demonstrated that students who specialised in History had relatively mixed views concerning their future career interests. Nevertheless, most students were likely to consider pursuing a career in History or other professions related to History other than teaching.

Attitudes push individuals to respond to objects, circumstances or suggestions in favorable or unfavorable ways. Sprinthall [19] identified two primary sources of attitudes. The first source is external influence and it usually comes from parents, friends and relatives. The second source is personal influence whereby an individual decides to make a choice when there are many options. A study by Rono and Cheruiyot [20] revealed that most learners are intrinsically and extrinsically motivated to study various subjects. He noted that teachers have a great influence on students' attitudes towards pursuing certain subjects. Teachers who apply good teaching approaches make students like their subjects compared to those who have poor teaching methodologies. He further observes that parents have a great influence on the development of students' attitude towards various subjects because they often pass their career preferences and dislikes to their children.Therefore, choice of career subjects is an intricate process influenced by individual and external influences.

Results presented in table 6 indicate that History was the first subject choice of 24(21.8\%) of male respondents and $31(28.2 \%)$ of female respondents. This finding reveals that more female students were comfortable with History as a first subject choice compared to the male ones. Generally, History was the first subject choice of the majority of the respondents 55(50\%). This implies that majority of students made the right subject choice and would not have any regret in future. History was the second subject choice of $28(25.5 \%)$ of male and $11(10 \%)$ of female respondents. This finding suggests that majority of the male respondents chose to study History due to the absence of other alternative subjects compared to the female respondents. Moreover, History was the third choice of more male $9(8.2 \%)$ than female $5(4.5 \%)$ respondents were. This finding further indicates that more male than female respondents selected History as a second or third option. Only $2(1.8 \%)$ of the respondents pursued history despite not having chosen it. When asked to rank their choice of History as a career subject, one of the male respondents noted that:

I did not attain enough aggregate points to study civil engineering, which was my first career choice. I therefore decided to pursue Bachelor of Education Arts. As a teacher trainee, I chose to specialize in History because it was one if my favourite subjects in secondary school. 
Table 7. Respondent's current opinion about choice of History

\begin{tabular}{|c|c|c|c|c|c|}
\hline \multirow{2}{*}{ Opinion on choice of History as a career subject } & \multicolumn{2}{|c|}{ Male } & \multicolumn{2}{c|}{ Female } & \multirow{2}{*}{ Total } \\
\cline { 2 - 6 } & Frequency & $\%$ & Frequency & $\%$ & \\
\hline Best choice ever made & 41 & $37.3 \%$ & 69 & $62.7 \%$ & $102(92.7 \%)$ \\
Some regrets about the course & 3 & $2.7 \%$ & 5 & $4.6 \%$ & $8(7.3 \%)$ \\
\hline Total & 48 & $43.6 \%$ & 62 & $56.4 \%$ & $110(100 \%)$ \\
\hline
\end{tabular}

Findings presented in table 7 indicate that $41(37.3 \%)$ of male and 69(62.7\%) of female respondents acknowledged that History was their best subject choice. This finding is consistent with the one in table 6 , which points out that more female than male respondents were happy with History as their first subject choice. Overall, majority of respondents102 $(92.7 \%)$ were happy with their choice of History. Conversely, a relatively small percentage $8(7.3 \%)$ of the respondents regretted choosing History as a career subject. These findings show that majority of students made informed subject choices. When asked about their current opinion about choice of history on of the respondents stated.

I have never regretted my choice of history as a career subject because it has enabled me to have a better understanding of the social, economic and political developments in my society. Furthermore, I aspire to pursue a career in History upon completing my studies because it is an interesting subject with many employment opportunities.

\section{Conclusions}

The findings of this study have pointed out that individual factors were the main determinants of students' selection of History as a career subject. Other factors, such as parental guidance, lecturer's influence, career guidance and counselling, job prospects and peer influence also had an impact on student's choice of History. The findings indicate that undergraduate students sought career guidance from various individuals due to limited institutional support on career guidance. Government sponsorship of university programmes influenced subject choices indirectly. Some government-sponsored students were compelled to do History as a second alternative because they never wanted to lose government sponsorship. The same cannot be said of the self-sponsored students who chose to specialize in History out of their volition. Majority of students who chose to pursue History were confident that it would enable them get good careers in future. This study has revealed that misinformation during selection of specialisation subjects can lead to poor performance of students in various teaching subjects and they can have difficulties in getting employment. Consequently, the University of Nairobi should provide proper guidance to students during selection of career subjects.

\section{Recommendations}

The following recommendations can be used to improve students' selection of career subjects.

1. Varsities should offer proper career guidance and counselling to undergraduate students to enable them make informed decisions on selection of courses. Teacher-trainees should be inducted properly to enable them select the right teaching subjects. In addition, tertiary learning institutions should carry out regular research on job market trends in the country to enable students make evidence-based decisions when choosing career subjects.

2. Lecturers can motivate learners to specialise in History through proper teaching and examination approaches.

3. Undergraduate students should be encouraged to attend career workshops to enable them learn about emerging job opportunities and marketable subjects. Career workshops can enable students' access professional guidance; hence, they will avoid misguidance from their peers and relatives.

4. The government should boost its funding of various university courses to enable many students pursue courses of their own choice. This can be achieved by reducing the cost of self-sponsored degree programmes through government bursary subsidies.

\section{REFERENCES}

[1] Alberts C, Mbalo N F, Ackermann C J. Adolescents' perceptions of the relevance of domains of identity formation: South African cross-cultural study. J. Youth and Adoles. 2003; 32(3): 169-184.

[2] Wilhelm W B. The relative influence of published teaching evaluations and other instructor attributes on course choice. J. Marketing Educ. 2004; 26(1): 17-30.

[3] Babad E, Tayeb A. Experimental analysis of students' course selection. Brit. J. Educ. Psych. 2003; 73(3): 373-393.

[4] Hooley T. How the internet changed career: framing the relationship between career development and online expertise. J.Gen. Instit. Career. 2012; 29: 3-13.

[5] Park T. Teaching as a career choice: attractors and deterrents identified by Grade 11 learners. South African J. Educ. 2006; 26(1), 143-156.

[6] Curran J M, Rosen D E. Student attitudes toward college courses: An examination of influences and intentions. J. 
Marketing Educ. 2006; 28(2): 135-148.

[7] Flowerday T, Schraw G. The effect of choice on cognitive and affective engagement. J. Educ. Res. 2003; 96(4): 207-215.

[8] Okeke A N. The impact of school subjects on the choice of careers and profession. West African J. Educ. 2000; 17(1): 5 11.

[9] Malgwi CA, Howe M A, Burnaby, P A. Influences on students' choice of college major. J. Educ. Bus. 2005; 80 (5): 275-282.

[10] Tenenbaum H. You'd be good at that': Gender patterns in parent-child talk about courses. Social Dev. 2008; 18(2): 447-463.

[11] Kniveton, B. The infleunces and motivations on which students bases their career. Res. Educ. 2004; 72: 47-57.

[12] Ahmed S, Sajjad M. Career Selection Behavior: Individual Perceptions and Counseling Effectiveness for Career Roles. J. Basic and Appl. Scient. Res. 2014; 4(2): 289-300.

[13] Radford, J, Govier, E. A Textbook of Psychology. London:
Routledge; 1991.

[14] Feldman R O. Understanding Psychology. New York: McGraw Hill; 1990.

[15] Kombo K D, Tromp D. Proposal and Thesis Wriitng: An introduction. Nairobi: Paulines Publishing Africa; 2011.

[16] Spraggs G. Outlaws and highwaymen. London: Pimlico; 2002 .

[17] Shumba A, Naong M. Factors Influencing Students' Career Choice and Aspirations in South Africa. J. Social Sci. 2012; 33(2): 169-178.

[18] Ackerman D S, Gross, B L. How many choices are good? Measurement of the effects of course choice on perceptions of a marketing option. J. Marketing. Educ. 2006; 28(1): 69-80.

[19] Sprinthall NA. Educational Psychology: A Development Approach Califonia: Worth Publishers; 1987.

[20] Rono D, Rono C. An Assessment of the Attitudes of Students towards History and Government in Selected Secondary Schools in Bomet County in Kenya. J.Educ. Pract. 2016; 7(19): 90-94. 